\title{
Determination of the Utilization and Effort Level of Mackerel Scad (Decapterus spp) in the Bitung Waters North Sulawesi
}

\author{
John Socrates Kekenusa, ${ }^{1, *}$, Sendy Beatrix Rondonuwu ${ }^{2}$, Marline Sofiana Paendong ${ }^{1}$ \\ ${ }^{1}$ Department of Mathematics, Sam Ratulangi University, Manado, Indonesia \\ ${ }^{2}$ Department of Biology, Sam Ratulangi University, Manado, Indonesia
}

Email address:

johnskekenusa@unsrat.ac.id (J. S. Kekenusa)

${ }^{*}$ Corresponding author

\section{To cite this article:}

John Socrates Kekenusa, Sendy Beatrix Rondonuwu, Marline Sofiana Paendong. Determination of the Utilization and Effort Level of Mackerel Scad (Decapterus spp) in the Bitung Waters North Sulawesi. Science Journal of Applied Mathematics and Statistics. Vol. 7, No. 6, 2019, pp. 103-111. doi: 10.11648/j.sjams.20190706.12

Received: September 19, 2019; Accepted: October 16, 2019; Published: October 28, 2019

\begin{abstract}
Determination of utilization level and effort level of scad mackerel (Decapterus spp) are very important to know the status of fisheries management. This fish needs to be managed well because even as a renewable natural resources, but can undergo depletion or extinction. One of the approach in the management of fish resources is by mathematics modeling. In this research using Surplus Production Model (SPM) with 5 estimator methods, that are: Schaefer, Fox, Schnute, Walter-Hilborn, and Clarke Yoshimoto Pooley. The analysis was performed aiming to get the best estimate for the surplus production model to determine the maximum sustainable yields (MSY), utilization level, and effort level of scad mackerel. The criteria of the best model (estimator) are: sign suitability of regression equation, value of coefficient determination, validation values (residual), and significance of regression coefficients. From the best model by using the formula can be determined the maximum sustainable yields (MSY) of catching, utilization level, and effort level. The data of catch and fishing effort of scad mackerel collected from the Marine and Fisheries the Bitung City and North Sulawesi Province from 1998 - 2016. The best SPM, which is used to assess the potential of scad mackerel is Schaefer Model. Optimal effort (EMSY) of 4,449 trips per year, with catch of optimal CMSY19,793.601 tons per year. The effort level for 2014 is $86.58 \%$, which shows the quite efficient effort, the utilization level of $73.10 \%$ showing the production still can be increased.
\end{abstract}

Keywords: Scad Mackerel, Surplus Production Model, Maximum Sustainable Yield, Bitung

\section{Introduction}

Mackerel scad (Decapterus spp) classified as important pelagic fisheries resources and one of the non-oil export commodity in North Sulawesi. Mackerel scad production in North Sulawesi (including Bitung waters) in 2016 reach 50,000 tons per year, with a value of about 100 billion rupiahs [1]. Research on mackerel scad generally discusses the exploitation to increase production, not much research on the status of utilization (including aspects of sustainability and efficiency) resources.

Catching mackerel scad in Bitung waters has lasted long enough, with high intensity. Data on the level of utilization of the fish resources are very important, as it will determine whether the resource use is less than optimal, optimal, or excessive. Exessive utilization of fish resources would threaten its sustainability. By knowing the level of resource utilization on the mackerel scad, is expected to be done in a planned and sustainable management.

The simplest model of the dynamics of fish populations is Simple Production Model (SPM), by treating the fish as a single biomass that can not be divided, which is subject to the rules of simple increases and decreases in biomass. This model, commomly used in the assessment of fish stocks using only the data of catch and fishing effort generally available.

This study aims to get the best SPM, as well as knowing how much the result of maximum sustainable yields (MSY), 
utilization level, and the level of effort of mackerel scad in the Bitung waters.

\section{Surplus Prodction Model}

The simplest model of the dynamics of fish populations is surplus production model that treats the fish population as a single biomass that cannot be divided, which is subject to the simple rules of the rise and decline. The production model is dependent on the amount of four kinds, namely: biomass population at a given time $t\left(B_{t}\right)$, catches for acertain time $t$ $\left(C_{t}\right)$, fishing effort at a certain time $t\left(E_{t}\right)$, and the natural growth rate constant (r) (Boer dan Aziz, 1995) [2].

This model was first developed by Schaefer, who was initially the same as the form of logistic model. According to Coppola and Pascoe [3], equation surplus consists of several constants that are affected by natural growth, the ability of fishing gear, and carrying capacity. Constants allegedly using models of biological parameter estimators of surplus production equation, namely the model: Equilibrium Schaefer, Schaefer Disequilibrium, Schnute, and WalterHilborn. Based on four models were selected the most appropriate or best fit of the estimation of others.

According to Sparre and Venema [4], formulas surplus production model (SPM) is valid only if the slope parameter (b) is negative, which means the addition of fishing effort will lead to a decrease in the catch per fishing effort. If the parameter $b$ positive value, then it can not be done estimating the optimum amount of stock and effort, but it can only be concluded that the addition of fishing effort is still possible to increase the catch.

Prediction of optimum fishing effort $\left(\mathrm{E}_{\mathrm{opt}}\right)$ and the maximum sustainable catch $\left(\mathrm{C}_{\mathrm{MSY}}\right)$ approached the SPM. Between the catch per unit of effort (CPUE) ang fishing effort can be either linear or exponential relationship [5]. SPM consists of two models, namely basic model of Schaefer (linear relationship) and the Gompertz model developed by Fox with forms exponential relationship [5].

\subsection{Schaefer Model}

SPM first developed by Schaefer, who was initially the same as the form of logistic growth model. The model is as follows:

$$
\frac{d B_{t}}{d t}=G\left(B_{t}\right)=r B_{t}\left(1-\frac{B_{t}}{K}\right)
$$

This equation does not include the effect of the catching, so Schaefer wrote back to:

$$
\frac{d B_{t}}{d t}=r B_{t t}\left(1-\frac{B_{t}}{K}\right)-C_{t}
$$

$\mathrm{K}$ is the carrying capacity of the marine environment, and $\mathrm{C}_{\mathrm{t}}$ is the catch that can be written:

$$
\mathrm{C}_{\mathrm{t}}=\mathrm{q} \mathrm{E} \mathrm{E}_{\mathrm{t}}
$$

$q$ is catchability, and $E_{t}$ is fishing effort. This equation can be written:

$$
\frac{C_{t}}{E_{t}}=q B_{t}=C P U E
$$

From the differential equation (2), the optimum catchment can be calculated at the time $\frac{d B_{t}}{d t}=0$, also called settlement at the point of balance (equilibrium), in the form of:

$$
\begin{gathered}
r B_{t}\left(1-\frac{B_{t}}{K}\right)-C_{t}=0, \text { or } \\
C_{t}=r B_{t}\left(1-\frac{B_{t}}{K}\right)=q E_{t} B_{t}
\end{gathered}
$$

From equation (3) and (5), find value of $B_{t}$ obtained as follow:

$$
B_{t}=K\left(1-\frac{q E_{t}}{r}\right.
$$

So that equation (5) becomes:

$$
\mathrm{C}_{\mathrm{t}}=\mathrm{qKE} \mathrm{E}_{\mathrm{t}}\left(1-\frac{q E_{t}}{r}\right)=\mathrm{q} \mathrm{KE}_{\mathrm{t}}-\frac{q^{2} K}{r} \mathrm{E}_{\mathrm{t}}^{2}
$$

Equation (7) is simplified further by Schaefer becomes:

$$
\begin{gathered}
\frac{C_{t}}{E_{t}}=a-b E_{t}, \text { or } \\
\mathrm{C}_{\mathrm{t}}=\mathrm{a} \mathrm{E}_{\mathrm{t}}-\mathrm{bE}_{\mathrm{t}}^{2}
\end{gathered}
$$

while $\mathrm{a}=\mathrm{q} \mathrm{K}$ and $b=\frac{q^{2} K}{r}$

This linear relationship is used widely for calculating $\mathrm{C}_{\mathrm{MSY}}$ through the determination of the first derivative of $C_{t}$ with $E_{t}$ to find optimal solutions, both to catch and fishing effort. The first derivative of $\mathrm{C}_{\mathrm{t}}$ to $\mathrm{E}_{\mathrm{t}}$ is: $\frac{d C_{t}}{d E_{t}}=a-2 b E_{t}$ in order to obtain the alleged $E_{\text {opt }}$ (optimum fishing effort) and $C_{M S Y}$ (maximum sustainable yields of catch), respectively:

$$
E_{O p t}=\frac{a}{2 b}=\frac{r}{2 q}
$$

By entering the value of $E_{o p t}$ in equation (8), will be obtained as follow:

$$
C_{M S Y}=a E_{t}-b E_{t}^{2}=a\left(\frac{a}{2 b}\right)-b\left(\frac{a}{2 b}\right)^{2}=\frac{a^{2}}{4 b}
$$

by substituting $\mathrm{a}=\mathrm{qK}$ and $b=\frac{q^{2} K}{r}$, will be obtained,

$$
C_{M S Y}=\frac{a^{2}}{4 b}=\frac{q^{2} K^{2}}{4 q^{2} K / r}=\frac{r K}{4}
$$

The value of $\mathrm{a}$ and $\mathrm{b}$ are estimated by the least squares method approach that is commonly used to estimate the 
coefficients of a simple regression equation. Furthermore, by including the value of $E_{o p t}$ in the equation (6) is obtained optimum biomass $\left(\mathrm{B}_{\mathrm{MSY}}\right)$ as follows:

$$
B_{M S Y}=K-\frac{K q}{r} E_{O p t}=K-\frac{K q}{r}\left(\frac{r}{2 q}\right)=K-\frac{K}{2}=\frac{K}{2}
$$

The value of parameter $\mathrm{q}, \mathrm{K}$, and $\mathrm{r}$ can be calculated using the Fox algorithm, as referenced in Sularso [5], as follows:

$$
\mathrm{q}_{\mathrm{t}}=\ln \left[\left|\left(z U_{t}^{-1}+\frac{1}{b}\right) /\left(z U_{t+1}^{-1}+\frac{1}{b}\right)\right|\right] /(z)
$$

where $\mathrm{z}=-(\mathrm{a} / \mathrm{b}) / \mathrm{E}^{*}, \mathrm{E}^{*}=\left(\mathrm{E}_{\mathrm{t}}+\mathrm{E}_{\mathrm{t}+1}\right) / 2, U_{t}=\frac{C_{t}}{E_{t}}$ and

the value of $\mathrm{q}$ is the geometric mean of $\mathrm{q}_{\mathrm{t}}$. From the values of $\mathrm{a}, \mathrm{b}$, and $\mathrm{q}$, can be calculated values of $\mathrm{K}$ and $\mathrm{r}$.

\subsection{Fox Model}

Model of Fox has several characteristics that are different from the model Schaefer, that it biomass growth following the Gompertz growth model [6]. The relation of CPUE with efforts (E) follows a negative exponential pattern:

$$
\mathrm{C}_{\mathrm{t}}=\mathrm{E}_{\mathrm{t}} \cdot \exp \left(\mathrm{a}-\mathrm{b} \mathrm{E}_{\mathrm{t}}\right)
$$

Efforts optimum is obtained by equating the first derivative of $C_{t}$ to $E_{t}$ equal to zero and find:

$$
\mathrm{E}_{\mathrm{opt}}=\frac{1}{b}
$$

The maximum sustainable yield of catch $\left(\mathrm{C}_{\mathrm{MSY}}\right)$ is obtained by inserting the value of the maximum effort into equation (13), and obtained:

$$
\mathrm{C}_{\mathrm{MSY}}=\frac{1}{b} \mathrm{e}^{\mathrm{a}-1}
$$

\subsection{Schnute Model}

Schnute, suggest another version of the SPM is dynamic and deterministic [7]. Schnute method is considered as a modification of the model in the form of discrete Schaefer (Roff, 1983, reffered by Tinungki) [8].

$$
\begin{aligned}
\ln \left(\frac{U_{t+1}}{U_{t}}\right) & =r-\frac{r}{q K}\left(\frac{U_{t}+U_{t+1}}{2}\right)-q\left(\frac{E_{t}+E_{t+1}}{2}\right) \\
= & a-b\left(\frac{U_{t}+U_{t+1}}{2}\right)-c\left(\frac{E_{t}+E_{t+1}}{2}\right)
\end{aligned}
$$

where $\mathrm{a}=\mathrm{r}, b=\frac{r}{q K}$, and $\mathrm{c}=\mathrm{q}$, is the regression coefficient estimators.

\subsection{Walter-Hilborn Model}

Walter and Hilborn (1976) referred by Tinungki [8], to develop other types of SPM, known as the regression model. Walter-Hilborn model, using a simple differential equation, by the following equation:

$$
\left.\frac{U_{t+1}}{U_{t}}\right)-1=r-\frac{r}{q K} U_{t}-q E_{t}=a-b U_{t}-c E_{t}
$$

\subsection{Clarke Yoshimoto Pooley (CYP) Model}

Estimation of biological parameter for the SPM can also be done through estimation techniques proposed be Clarke, Yoshimoto, and Pooley (Fauzi and Anna) [9]. The parameters which allegedly is $\mathrm{r}, \mathrm{K}$, and $\mathrm{q}$, the model is expressed as follows:

$$
\ln \left(U_{t+1}\right)=\left(\frac{2 r}{2+r}\right) \ln (q K)+\frac{2-r}{2+r} \ln \left(U_{t}\right)-\frac{q}{2+r}\left(\frac{E_{t}+E_{t+1}}{2}\right)
$$

where $a^{\prime}=\frac{2 r}{2+r}, \quad a=a^{\prime} \ln (q K) \quad b=\frac{2-r}{2+r} \quad c=\frac{q}{2+r}$ thus equation (18) can be written in the form:

$$
\begin{gathered}
\ln \left(U_{t+1}\right)=a^{\prime} \ln (q K)+b \ln \left(U_{t}\right)-c\left(E_{t}+E_{t+1}\right) \\
=a+b\left(\ln U_{t}\right)-c\left(E_{t}+E_{t+1}\right)
\end{gathered}
$$

\section{Research Methods}

\subsection{Source of Data}

The primary and secondary data of mackerel scad catching is collected from the Bitung waters. Production and fishing effort data collected from the Marine and Fisheries Service of Bitung City and North Sulawesi Province during 1998-2016.

Data (variables) used for the analysis of the SPM is the data of catch $\left(C_{t}\right)$ per year and fishing effort $\left(E_{t}\right)$ per year, and CPUE (Catch Per Unit of Effort). The data (variables) used for the analysis of the SPM is a follows:

1. The catch $\left(\mathrm{C}_{t}\right)$ : weigkt of fish landed (tons) in year $t$

2. The effort of catching $\left(E_{t}\right)$ : the number of fishing boat landing (trips) in year $\mathrm{t}$

3. $\frac{C t}{E t}$ catch per unit of efforts

\subsection{Methods of Data Analysis}

The models estimator who analyzed and evaluated are Schaefer, Fox, Schnute, Walter-Hilborn, and ClarkeYoshimoto-Pooley (CYP). Based on results of statistical evaluation (mark of conformity, the value of $\mathrm{R}^{2}$, the validation (residual) value, and significance of the regression coefficient of the model), we get the "best" as estimator. From the best of model can be calculated $\mathrm{C}_{\mathrm{MSY}}$ value, optimum fishing affort ( $\left.\mathrm{E}_{\mathrm{MSY}}\right)$, utilization: $\mathrm{n}$ level, and the level of effort of mackerel scad.

\section{Result and Discussion}

Catch of mackerel scad fisheries in the Bitung waters fluctuate from year to year. Data catching in 1998-2016, are presented in Table 1 . 
Table 1. Total catch, fishing efforts, and CPUE mackerel scad in Bitung waters of 1998-2016.

\begin{tabular}{llll}
\hline \multicolumn{2}{l}{ Years Catch (tons) } & Efforts (trips) & $\mathbf{C P U E}=\frac{\boldsymbol{C}_{t}}{\boldsymbol{E}_{t}}$ (ton/trip) \\
\hline 1998 & $16,424.9$ & 3,189 & 5.1505 \\
1999 & $16,226.6$ & 2,449 & 6.6258 \\
2000 & $14,818.4$ & 2,681 & 5.5272 \\
2001 & $13,645.9$ & 3,842 & 3.5518 \\
2002 & $20,147.2$ & 4,216 & 4.7787 \\
2003 & $15,356.5$ & 3,360 & 4.5704 \\
2004 & $13,772.1$ & 2,114 & 6.5147 \\
2005 & $13,357.0$ & 2,014 & 6.6321 \\
2006 & $19,236.7$ & 2,986 & 6.4423 \\
2007 & $19,485.0$ & 3,184 & 6.1197 \\
2008 & $21,347.3$ & 4,526 & 4.7166 \\
2009 & $21,817.5$ & 4,814 & 4.5321 \\
2010 & $20,332.7$ & 4,765 & 4.2671 \\
2011 & $14,394.1$ & 4,164 & 3.4568 \\
2012 & $14,535.8$ & 4,494 & 3.2345 \\
2013 & $10,966.2$ & 4,684 & 2.3412 \\
2014 & $14,469.7$ & 3,852 & 3,7564 \\
2015 & $14,421.6$ & 3,761 & 3.8345 \\
2016 & $14,234.0$ & 3,452 & 4.1234 \\
\hline
\end{tabular}

Source: Calculated from the Marine and Fisheries Service Bitung City and North Sulawesi Province data

The results of the regression analysis for the SPM is presented in Appendix 1, which is described as follows:

\subsection{Schaefer Model}

From the analysis of regression equation $\frac{C_{t}}{E_{t}}=8.898-0.001 E_{t}$ with a coefficient of determination $\left(\mathrm{R}^{2}=\right.$ $0.639)$ and a significance level of $\mathrm{p}<0.01$. Thus, a production model estimator catches Schaefer model according to equation (8) is: $\mathrm{C}_{\mathrm{t}}=8.898 \mathrm{E}_{\mathrm{t}}-0.001 \mathrm{E}_{\mathrm{t}}^{2}$.

\subsection{Fox Model}

From the results of the regression analysis for Fox model is: $\operatorname{Ln} \mathrm{C}_{\mathrm{t}}=2.397-0.000243 \mathrm{E}_{\mathrm{t}}$, with $\mathrm{R}^{2}=0.577(\mathrm{p}<0.01)$. Estimates of catches corresponding to the model Fox equation (13):

$$
\mathrm{C}_{\mathrm{t}}=\mathrm{E}_{\mathrm{t}} \cdot \mathrm{e}^{\left(2.397-0.000243 \mathrm{E}_{\mathrm{t}}\right.}
$$

\subsection{Schnute Model}

Schnute method according to equation (16), obtained regression equation:

$$
\ln \left(\frac{U_{t+1}}{U_{t}}\right)=0.647-0.059\left(\frac{U_{t}+U_{t+1}}{2}\right)-0.000105\left(\frac{E_{t}+E_{t+1}}{2}\right)
$$

with $\mathrm{R}^{2}=0.043$, and all the regression coefficient were not significant $(\mathrm{p}>0.05)$.

\subsection{Walter - Hilborn Model}

In Walter-Hilborn method using equation (17) derived regression equation :

$$
\frac{U_{t+1}}{U_{t}}-1=1.386-0.169 U_{t}-0.000156 E_{t}
$$

with $\mathrm{R}^{2}=0.282$, and all the regression coefficient were not significant $(\mathrm{p}>0.05)$.

\subsection{Clarke Yoshimoto Pooley (CYP) Model}

The regression equation CYP method, according to equation (19):

$\ln \left(U_{t+1}\right)=1.838+0.272 \ln \left(U_{t}\right)-0.000102\left(E_{t}+\right.$ $\left.E_{t+1}\right)$, with $\mathrm{R}^{2}=0.634$, not all the regression coefficient were significant.

\section{Discussion}

The results of calculation for validation (residual) SPM of 5 models is presented in Appendix 2, which is summarized in

\begin{tabular}{|c|c|c|c|c|c|}
\hline & \multicolumn{5}{|l|}{ Model: } \\
\hline & Schaefer & Fox & Schnute & Walter-Hilborn & CYP Model \\
\hline Sign Suitability & Appropriate & Appropriate & Appropriate & Appropriate & Appropriate \\
\hline $\mathrm{R}^{2}$ Value & 0.639 & 0.557 & 0.043 & 0.282 & 0.634 \\
\hline Validation Value & 0.2043 & 0.1513 & 0.1569 & 0.1768 & 1.0215 \\
\hline Significance Coefficient & Significant & Significant & Not significant & Not all significant & Not all significant \\
\hline
\end{tabular}
Table 2.

Table 2. Results of the surplus production model validation.

From the results of the calculation in Table 2, it appears that the most appropriate is Schaefer model with the largest $\mathrm{R}^{2}=$ 0.639 and validation (residual value) is relatively small. Schaefer model obtained value of $\mathrm{a}=8.898$ and $\mathrm{b}=0.001$, with equation (9) and (10) can be calculated optimum value of effort $\left(\mathrm{E}_{\mathrm{opt}}\right)$ and the maximum sustainable catch $\left(\mathrm{C}_{\mathrm{MSY}}\right)$ as follows:

$$
\mathrm{E}_{\mathrm{opt}}=\frac{a}{2 b}=\frac{8.898}{2(0.001)}=4,449
$$

trips per year

$$
\mathrm{C}_{\mathrm{MSY}}=\frac{a^{2}}{4 b}=\frac{8.898^{2}}{4(0.001)}=19,793.601
$$

tons per year

This mean that in order to preserve the mackerel scad fisheries resources technically and biologically, in a year the number of units should not exeed 4,449 trips. To preserve the mackerel scad resources in Bitung waters, the maximum of fish that can be caught at 19,793.601 tons per year. Furthermore, from the value of $\mathrm{E}_{\mathrm{opt}}$ and $\mathrm{C}_{\mathrm{MSY}}$ can be calculated fishing effort level and utilization level of mackerel scad for a particular year for example in 2014, as follows:

The level of effort in $2014=\frac{E_{2014}}{E_{\text {opt }}} \times 100 \%=\frac{3,852}{4,449}=86.58 \%$

The utilization level in $2014=\frac{C_{2014}}{C_{M S Y}} \times 100 \%=\frac{14,469.7}{19,793.601}=$ $73.10 \%$ 
From the calculation, it turns out mackerel scad fishing effort at the Bitung waters in 2014 (86.58\%), lower than the optimum effort so that still can be increased. The utilization level for the year $2014(73.10 \%)$, is lower than the optimum level, its mean the catching can be increased.

The researchs to know utilization level and effort level for pelagic fish, especially to little tuna in North Sulawesi waters by Kekenusa et al in Talaud and Bitung waters showing that the overfishing of production and inefficient of effort [10], [11].

The distribution of scad mackerel (Decapterus spp) in almost of regións in Indonesia, especially in Java Waters, South of Makasar, until North Sulawesi Waters [12]. As a comparison to scad mackerel in other waters in Indonesia, the catches of optimal $\left(\mathrm{C}_{\mathrm{MSY}}\right)$ of scad mackerel in East of South East Sulawesi waters is 5,747.61 tons per year [13]. Scad mackerel in South East Sulawesi waters showing the intensive production [14]. In South Sulawesi at Flores Sea Waters, $\mathrm{C}_{\mathrm{MSY}}$ of scad mackerel is 10,456 tons per year, with the effort level $83.15 \%$ and the utilization level $76.60 \%$, showing the intensive exploitation [15]. From these data, for scad mackerel in East Indonesia Waters (include in Bitung), generally the production still can be increased.

This research describes the use of some statistical criteria in selecting the best surplus production model. By applying some statistical criteria in selecting a surplus production model, will obtain better results. Researchers in the field of fisheries get guidelines for setting selection criteria for surplus production models, as well as avoiding the direct application of one model in analyzing the surplus production model in a waters.

\section{Conclusions and Recommendation}

\subsection{Conclusion}

1. The surplus production model that can be used to examine the catch of mackerel scad in the Bitung waters is Schaefer model, by the equation: $C_{t}=8.898 E_{t}-0.001 E_{t}^{2}$.

2. The maximum sustainable yield of mackerel scad $\mathrm{C}_{\mathrm{MSY}}$ is 19,793.601 tons per year, obtained at the level of fishing effort $\mathrm{E}_{\mathrm{opt}} 4,449$ trips. According to data at year 2014, for next years the catch and effort still can be increased.

\subsection{Suggestion}

1. In applying surplus production model in a waters location, not only directly using one particular model, but should use some of the models are chosen based on statistical criteria. The criteria involve, among others: suitability sign of the coefficient of models, coeffient of determination $\left(\mathrm{R}^{2}\right)$, the value of validation (residual), and the significance of the regression coefficients.

2. The catchs and efforts for mackerel scad in Bitung waters are lower than the optimum, so that still can be increased.

\section{Appendix}

\section{Appendix 1. Regression Analysis of Surplus Production Model of Mackerel scad Data in Bitung Waters}

\section{Model Schaefer}

Table 3. Model Summary.

\begin{tabular}{lllll}
\hline Model & R & R square & Adjusted R square & Std Error The Estimate \\
\hline 1 & .800 & .639 & .618 & .7900942 \\
\hline
\end{tabular}

a. Predictors: (Constant), $\mathrm{E}_{\mathrm{t}}$

Table 4. Coefficients regression.

\begin{tabular}{lllll}
\hline \multirow{2}{*}{ Model } & \multicolumn{2}{l}{ Unstandardized Coefficient } & \multicolumn{3}{l}{ Standardized oefficient } \\
\cline { 2 - 5 } & B & Std. Error & Beta & t \\
\hline (Constant) & 8.898 & .778 & & 11.438 \\
1 & & & & .000 \\
Et & -.001 & .000 & -.800 & -5.489 \\
\hline
\end{tabular}

a. Dependent Variabel $U_{t}$

Table 5. Anova.

\begin{tabular}{llllll}
\hline Model & & Sum of Squares & Df & Mean Squares & F \\
\hline \multirow{3}{*}{1} & Regression & 18.807 & 1 & 18.807 & 30.127 \\
& Residual & 10.612 & 17 & .624 & $0.000 \mathrm{~b}$ \\
& Total & 29.419 & 18 & & \\
\hline
\end{tabular}

a. Dependent Variabel: $U_{t}$

b. Predictor: (Constant), $\mathrm{E}_{\mathrm{t}}$ 
Model Fox

Table 6. Model Summary.

\begin{tabular}{|c|c|c|c|c|c|}
\hline Model & $\overline{\mathbf{R}}$ & R square & & Adjusted R square & Std Error the Estimate \\
\hline 1 & 760 & 577 & & 552 & 1900054 \\
\hline \multicolumn{6}{|c|}{ a. Predictors: (Constant), $\mathrm{E}_{\mathrm{t}}$} \\
\hline \multirow{2}{*}{ Model } & \multicolumn{2}{|c|}{ Unstandardized Coefficient } & \multicolumn{3}{|c|}{ Standardized oefficient } \\
\hline & B & Std. Error & Beta & $t$ & Sig. \\
\hline $\begin{array}{l}\text { (Constant) } \\
1\end{array}$ & 2.397 & .187 & & 12.815 & .000 \\
\hline Et & .000243 & .000 & -.760 & -4.818 & .000 \\
\hline
\end{tabular}

a. Dependent Variabel Ln $U_{t}$

Table 8. Anova.

\begin{tabular}{lllllll}
\hline Model & & Sum of Squares & Df & Mean Squares & F & Sig. \\
\hline \multirow{3}{*}{1} & Regression & .838 & 1 & .838 & 23.215 & $0.000 \mathrm{~b}$ \\
& Residual & .614 & 17 & .036 & & \\
& Total & 1.452 & 18 & & & \\
\hline
\end{tabular}

a. Dependent Variabel: $\operatorname{Ln} U_{t}$

b. Predictor: (Constant), $\mathrm{E}_{\mathrm{t}}$

\section{Model Schnute}

Table 9. Model Summary.

\begin{tabular}{llll}
\hline Model & R & R square & Adjusted R square \\
\hline 1 & .208 & .043 & -.084 \\
\hline
\end{tabular}

a. Predictors: (Constant), $\mathrm{E}_{\mathrm{t}}$

Table 10. Coefficients Regression.

\begin{tabular}{|c|c|c|c|c|c|c|}
\hline \multirow{2}{*}{ Model } & & \multicolumn{2}{|c|}{ Unstandardized Coefficient } & \multicolumn{3}{|c|}{ Standardized Coefficient } \\
\hline & & $\mathbf{B}$ & Std. Error & Beta & $\mathbf{t}$ & Sig. \\
\hline & (Constant) & .846 & .846 & & .765 & .456 \\
\hline 1 & $\left(\mathrm{U}_{\mathrm{t}+1}+\mathrm{U}_{\mathrm{t}}\right) / 2$ & -.059 & -089 & -.297 & -.663 & .518 \\
\hline
\end{tabular}

a. Dependent Variabel: $\operatorname{Ln}\left(\mathrm{U}_{\mathrm{t}+1} / \mathrm{U}_{\mathrm{t}}\right)$

Table 11. Anova.

\begin{tabular}{llllll}
\hline Model & & Sum of Squares & Df & Mean Squares & F \\
\hline \multirow{3}{*}{1} & Regression & .042 & 2 & .021 & .340 \\
& Residual & .922 & 15 & .061 & $.717 \mathrm{~b}$ \\
& Total & .964 & 17 & & \\
\hline
\end{tabular}

a. Dependent Variabel: $\operatorname{Ln}\left(\mathrm{U}_{\mathrm{t}+1} / \mathrm{U}_{\mathrm{t}}\right)$

b. Predictor: (Constant), $\left(\mathrm{E}_{\mathrm{t}+1}+\mathrm{E}_{\mathrm{t}}\right) / 2,\left(\mathrm{U}_{\mathrm{t}+1}+\mathrm{U}_{\mathrm{t}}\right) / 2$

Model Walter-Hilborn

Table 12. Model Summary.

\begin{tabular}{llll}
\hline Model & R & R square & Adjusted R square \\
\hline 1 & $.531 \mathrm{a}$ & .186 & .2277233 \\
\hline
\end{tabular}

a. Predictors: (Constant), $\mathrm{U}_{\mathrm{t}}$ (trip), $\mathrm{C}_{\mathrm{t}}$ per $\mathrm{E}_{\mathrm{t}}$

Table 13. Coefficient Regression.

\begin{tabular}{|c|c|c|c|c|c|c|}
\hline \multirow{2}{*}{ Model } & & \multicolumn{2}{|c|}{ Unstandardized Coefficient } & \multicolumn{2}{|c|}{ Standardized Coefficient } & \multirow[b]{2}{*}{ Sig. } \\
\hline & & B & Std. Error & Beta & $\mathbf{t}$ & \\
\hline \multirow{3}{*}{1} & (Constant) & 1.386 & .687 & & 2.019 & .062 \\
\hline & Ct per Et & -.169 & .072 & -.873 & -2.336 & .034 \\
\hline & $\mathrm{E}_{\mathrm{t}}$ (trip) & -.000156 & .000 & -.564 & -1.508 & .152 \\
\hline
\end{tabular}

a. Dependent Variable: (Ut+1/Ut - 1) 
Table 14. Anova.

\begin{tabular}{lllllll}
\hline Model & & Sum of Squares & Df & Mean Squares & F & Sig. \\
\hline \multirow{3}{*}{1} & Regression & .306 & 2 & .153 & 2.947 & $.083^{\mathrm{b}}$ \\
& Residual & .778 & 15 & .052 & & \\
& Total & 1.083 & 17 & & & \\
\hline
\end{tabular}

a. Dependent Variable: $(\mathrm{Ut}+1 / \mathrm{Ut}-1)$

b. Predictors: (Constant), $\mathrm{E}_{\mathrm{t}}$ (trip), Ct per Et

\section{Model CYP}

Table 15. Model Summary.

\begin{tabular}{llll}
\hline Model & R & R square & Adjusted R square \\
\hline 1 & $796^{\mathrm{a}}$ & .634 & .585 \\
\hline
\end{tabular}

a. Predictors: (Constant), Et + Et+1, Ln CPUE

Table 16. Coefficients Regression.

\begin{tabular}{|c|c|c|c|c|c|c|}
\hline \multirow{2}{*}{ Model } & & \multicolumn{2}{|c|}{ Unstandardized Coefficient } & \multicolumn{3}{|c|}{ Standardized Coefficient } \\
\hline & & B & Std. Error & Beta & $\mathbf{t}$ & Sig. \\
\hline \multirow{3}{*}{1} & (Constant) & 1.838 & .535 & & 3.434 & 004 \\
\hline & Ln CPUE & .272 & .210 & .272 & 1.297 & .214 \\
\hline & $E t+E t+1$ & -.000102 & .000 & -.588 & -2.803 & 013 \\
\hline
\end{tabular}

a. Dependent Variable: Ln (Ut+1)

Table 17. Anova.

\begin{tabular}{llllll}
\hline Model & & Sum of Squares & Df & Mean Squares & F \\
\hline \multirow{3}{*}{1} & Regression & .911 & 2 & Sig. & 12.985 \\
& Residual & .526 & 15 & .455 & $.001^{\mathrm{b}}$ \\
& Total & 1.083 & 17 & .035 & \\
\hline
\end{tabular}

a. Dependent Variable: $\mathrm{Ln}(\mathrm{Ut}+1)$

b. Predictors: (Constant), Et $+\mathrm{Et}+1, \mathrm{Ln}$ CPUE

Appendix 2. Validation (Residual) of Surplus Production Model of Mackerel Scad Data

Table 18. Validation (residual) of model.

\begin{tabular}{|c|c|c|c|c|c|c|c|}
\hline \multirow{2}{*}{ Years } & \multirow{2}{*}{$\mathrm{C}_{\mathrm{t}}($ tons $)$} & \multirow{2}{*}{$E_{t}($ trips $)$} & \multicolumn{5}{|c|}{ Validation: $\operatorname{Abs}\left(\mathrm{Ct}-\widehat{C}_{t}\right) / \mathrm{Ct}$} \\
\hline & & & Schaefer & Fox & Schnute & Walter-Hilborn & CYP \\
\hline 1998 & $16,424.9$ & 3,189 & .4235 & .2165 & .1404 & .3138 & 1.4881 \\
\hline 1999 & $16,226.6$ & 2,449 & .0202 & .1744 & .2933 & .0955 & .7749 \\
\hline 2000 & $14,818.4$ & 2,681 & .1248 & .0365 & .1109 & .0375 & .7984 \\
\hline 2001 & $13,645.9$ & 3,842 & .4235 & .2165 & .1404 & .3138 & 1.4881 \\
\hline 2002 & $20,147.2$ & 4,216 & .0202 & .1744 & .2933 & .0955 & .7749 \\
\hline 2003 & $15,356.5$ & 3,360 & .2117 & .0628 & .0761 & .1180 & 1.0337 \\
\hline 2004 & $13,772.1$ & 2,114 & .0413 & .0093 & .0992 & .0397 & .6085 \\
\hline 2005 & $13,357.0$ & 2,014 & .0380 & .0158 & .1069 & .0428 & .5943 \\
\hline 2006 & $19,236.7$ & 2,986 & .0823 & .1743 & .1321 & .1534 & .4980 \\
\hline 2007 & $19,485.0$ & 3,184 & .0663 & .1716 & .1446 & .1386 & .5462 \\
\hline 2008 & $21,347.3$ & 4,526 & .0731 & .2242 & .4023 & .1441 & .7358 \\
\hline 2009 & $21,817.5$ & 4,814 & .0989 & .2472 & .4923 & .1677 & .7461 \\
\hline 2010 & $20,332.7$ & 4,765 & .0314 & .1909 & .4401 & .1054 & .8655 \\
\hline 2011 & $14,394.1$ & 4,164 & .3695 & .1558 & .0040 & .2642 & 1.4679 \\
\hline 2012 & $14,535.8$ & 4,494 & .3616 & .1401 & .1106 & .2572 & 1.5406 \\
\hline 2013 & $10,966.2$ & 4,684 & .7999 & .5040 & .0827 & .6623 & 2.4329 \\
\hline 2014 & $14,469.7$ & 3,852 & .3433 & .1474 & .0735 & .2398 & 1.3500 \\
\hline 2015 & $14,421.6$ & 3,761 & .3397 & .1492 & .0943 & .2364 & 1.3247 \\
\hline 2016 & $14,234.0$ & 3,452 & .3208 & .1520 & .1525 & .2187 & 1.2330 \\
\hline Mean & $16,262.60$ & $3,607.74$ & 0.2043 & 0.1513 & 0.1569 & 0.1768 & 1.0215 \\
\hline
\end{tabular}

1. Schaefer Model:

$$
\hat{C}_{t}=8.898 E_{t}-0,001 E_{t}^{2}
$$

2. Fox Model:

3. Schnute Model:

$$
\hat{C}_{t}=E_{t} \cdot e^{\left(2.397-0,000243 E_{t}\right)}
$$




$$
\begin{gathered}
\hat{Y}=a-b X_{1}-c X_{2}=0.647-0.059 X_{1}-0.00105 X_{2} \\
\mathrm{r}=\mathrm{a}=0.647 \mathrm{q}=\mathrm{c}=0.000105 \mathrm{~b}=\frac{r}{K q}=0.059 \\
\mathrm{~K}=\frac{r}{b q}=\frac{0.647}{(0.059)(0.000105)}=104,439.064 \\
\hat{C}_{t}=K q E_{t}-\frac{K q^{2}}{r} E_{t}^{2}=10.966 \mathrm{E}_{\mathrm{t}}-0.0018 \mathrm{E}_{\mathrm{t}}^{2}
\end{gathered}
$$

4. Walter-Hilborn Model:

$$
\begin{gathered}
\hat{Y}=a-b X_{1}-c X_{2}=1.386-0.169 X_{1}-0.000156 X_{2} \\
\mathrm{r}=\mathrm{a}=1.386 \mathrm{q}=\mathrm{c}=0.000156 \mathrm{~b}=\frac{r}{K q}=0.169 \\
\mathrm{~K}=\frac{r}{b q}=\frac{1.386}{(0.169)(0,000156)}=52,571.69 \\
\hat{C}_{t}=K q E_{t}-\frac{K q^{2}}{r} E_{t}^{2}=8.2012 E_{t}-0.000923 E_{t}^{2}
\end{gathered}
$$

5. CYP Model:

$$
\begin{gathered}
\hat{Y}=a+b X_{1}-c X_{2}=1.838-0.272 X_{1}-0.000102 X_{2} \\
r=\frac{2(1-b)}{1+b}=\frac{2(1-0.272)}{1+0.272}=1.1447 \\
q=-c(2-r)=0.000102(2-1.1447)=0.000087 \\
Q=\frac{a(2+r)}{2 r}=\frac{1.838(2+1.1447)}{2(1.1447)}=2.5247 \\
\mathrm{~K}=\frac{e^{Q}}{q}=\frac{e^{2.5247}}{0.000087}=143,530.443 \\
\hat{C}_{t}=K q E_{t}-\frac{K q^{2}}{r} E_{t}^{2}=12.487 E_{t}-0.00095 E_{t}^{2}
\end{gathered}
$$

\section{References}

[1] [DKP] Dinas Kelautan dan Perikanan Provinsi Sulawesi Utara. 2016. Statistik Perikanan Tangkap Provinsi Sulawesi Utara Tahun 2015.

[2] Boer, M., and K. A. Azis. 1995. Prinsip-prinsip Dasar Pengelolaan Sumberdaya Perikanan Melalui Pendekatan Bio-Ekonomi. Jurnal Ilmu-ilmu Perairan dan Perikanan III (2): 109-119.

[3] Coppola G., and S. Pascoe. 1996. A Surplus Production Model with a non-linear Catch-Effort Relationship. (Research Paper 105) Center for the Economics and Managemant of Aquatic Resources University of Portsmouth.

[4] Sparre, P. and S. C. Venema. 1999. Introduksi Pengkajian Stok Ikan Tropis. Buku 1 Manual. (Terjemahan J. Widodo. I. G. S. Merta, S. Nurhakim, dan M. Badrudin). Pusat Penelitian dan Pengembangan Perikanan, Badan Penelitian dan Pengembangan Pertanian (Kerjasama dengan Organisasi Pangan dan Pertanian Perserikatan Bangsa-bangsa). Jakarta. 438 hal.

[5] Gulland, J. A. 1983. Fishing and Stock of Fish at Iceland.
Mui. `Agric. Fish Food, Invest. (Ser.2) 23 (4): 52 - 70.

[6] Sularso, A. 2005. Alternatif Pengelolaan Perikanan Udang di Laut Arafura. Disertasi (Tidak Dipublikasikan). Sekolah Pascasarjana Institut Pertanian Bogor. Bogor. 130 hal.

[7] Fox, W. W. 1970. An Exponential Surplus Yield Model for Optimazing Exploited Fish Population. Trans. Am. Fish Soc. 99 (1): 80-88.

[8] Tinungki, G. M. 2005. Evaluasi Model Produksi Surplus dalam Menduga Hasil Tangkapan Maksimum Lestari untuk Menunjang Pengelolaan Perikanan Lemuru Di Selat Bali. Disertasi (Tidak Dipublikasikan). Sekolah Pascasarjana Institut Pertanian Bogor. Bogor. 207 hal.

[9] Fauzi, A., dan S. Anna. 2005. Pemodelan Sumberdaya Perikanan dan Kelautan untuk Analisis Kebijakan. PT. Gramedia Pustaka Utama, Jakarta.

[10] Kekenusa, J. S, Marline S. Paendong, Winsy Ch. D. Weku, and Sendy B. Rondonuwu. 2015. Determination of the Status of Utilization and Management Scenarios Bonito (Auxis rochei) Caught in the Talaud Waters North Sulawesi. Sci J. of Applied Mathematics and Statistics 2015: 3 (2): 39-46. 
[11] Kekenusa, J. S, Sendy B. Rondonuwu, and Marline S. Paendong. 2018. Determination of the Status of Utilization and Effort of Bonito (Auxis rochei) Caught in the Bitung Waters North Sulawesi. International Journal of ChemTech Research 2018, 11 (2): 340-354.

[12] Sumarsono, A. Zamroni. 2013. Sebaran Unit Stok Ikan Layang (Decapterus spp) dan Risiko PengelolaanIkan Pelagis Kecil di Laut Jawa. Jurnal Kebijakan perikanan Indonesia. Vol 5 No.1 Mei 2013: 17-24.

[13] Safrudin. 2013. Distribusi Ikan Layang (Decapterus spp) Hubungannya dengan Kondisi Oseanografi di Perairan Kabupaten Pangkep Sulawesi Selatan. Torani (Jurnal Ilmu Kelautan dan Perikanan). Vol 23 (3) Des 2013: 150-156.
[14] Mahmud, A., R. L. Bubun. 2015. Potensi Lestari Ikan Layang (Decapterus spp) Berdasarkan Hasil Tangkapan Pukat Cincin di Perairan Timur Sulawesi Tenggara. Jurnal Teknologi Perikanan dan Kelautan Vol 6 No 2 2015: 159-168. E-journal http://dx.doi.org/10.24319/jtpk.6 10 Agustus 2018.

[15] Latukonsina, H. 2010. Pendugaan Potensi dan Tingkat Pemanfaatan Ikan Layang (Decapterus spp) di Perairan Laut Flores Sulawesi Selatan. Jurnal Ilmiah Agribisnis dan

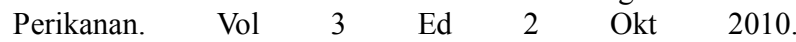
Http://ejournal.stipwunaraha.ac.id 09 Agustus 2018. 